SHORT REPORT

\title{
Infant growth and income 50 years later
}

\author{
D J P Barker, J G Eriksson, T Forsén, C Osmond
}

Arch Dis Child 2005;90:272-273. doi: 10.1136/adc.2003.033464

Among 4630 boys, irrespective of the social class into which they were born, those who grew slowly during infancy had poor educational achievements and had lower incomes than those who grew more rapidly. One interpretation of this is that biological processes linked to slow infant growth may lead to lifelong impairment of cognitive function.

$\mathrm{n}$ the famous study of children born in Newcastle-on-Tyne during 1947, the "Thousand Families Study", one of the strongest predictors of intelligence at age 11 years was height at 3 years. ${ }^{1}$ Taller children performed better across a range of tests of verbal reasoning, English, and arithmetic. In democratic societies higher intelligence is often related to higher earnings. We have therefore examined the links between early growth and income in a group of 50 year old men.

\section{PARTICIPANTS, METHODS, AND RESULTS}

We studied 4630 men born in Helsinki, Finland, during 193444. ${ }^{2}$ Eighty four per cent of the boys identified through birth and clinic records were still alive and resident in Finland in 1971. On average, the height of each man had been measured 18 times between birth and age 12. We linked these measurements with information on income and occupation taken from the 1990 census and with records of the level of education achieved: the men were grouped into two levels of education: high (upper secondary and tertiary); and middle and low combined. ${ }^{3}$ We found that boys who were taller at any age between birth and 12 years had higher incomes in 1990. This association, however, was established during infancy. The correlation coefficients were $0.04(\mathrm{p}=0.01)$ at birth, $0.09(\mathrm{p}<0.0001)$ at 1 year, and remained around 0.10 thereafter. Table 1 shows that income rose progressively between men who were $72 \mathrm{~cm}$ or less in length at 1 year and those who were more than $80 \mathrm{~cm}$. To examine the effects of growth at later ages we converted each measurement of height for each boy to a standard deviation score at each birthday up to the age of 12 years. ${ }^{2}$ Change in score between 1 and 12 years was not associated with later income $(p=0.27)$. Sixty seven per cent of the men were born into labourers' rather than middle class households. Although they tended to have lower incomes, short length at 1 year was related to lower income within both labourers' and middle class households. Across the height groups shown in the table, the mean annual incomes of men born into labourers' households ranged from 96.1 to 138.8 thousand Finnish marks, compared with 135.3 to 181.1 in middle class households. After allowing for father's occupation, each $2 \mathrm{~cm}$ increase in length between birth and 1 year was associated with a $3.5 \%(95 \%$ CI 1.6 to $5.4, p=0.0002)$ increase in income. Nineteen per cent of the men were classified as having reached a high level of education. ${ }^{3}$ Table 1 shows that fewer of the boys who were short at age 1 achieved a high level of education, and more were later employed as labourers. Both associations were similarly strong among men who were born into labourers' or middle class families.

\section{DISCUSSION}

Irrespective of social class at birth, men who grew slowly between birth and 1 year had lower income in later life. The heights of the boys in our study were similar to those in Britain today. ${ }^{4}$ Our findings are consistent with those in Newcastle, ${ }^{1}$ in that they point to the importance of early childhood growth on later cognitive function. In our study most of the effect of early growth on later income was determined by growth during infancy. Change in standard deviation score for height between 1 and 12 years of age was not associated with later income. Slow infant growth may be accompanied by slow brain growth. Alternatively infants that are less well nourished or recurrently ill may reduce their physical activity and sensory stimulation. Another possibility is that the short adult stature that results from slow infant growth may be a disadvantage in obtaining well-paid employment. In the Newcastle study, however, short stature at age 3 years predicted lower intelligence at age 11 years, while in our data short length at age 1 year similarly predicted poor educational achievement in later childhood

Table 1 Length of 4630 men at 1 year of age related to later education, income, and occupation

\begin{tabular}{|c|c|c|c|c|}
\hline \multirow{2}{*}{$\begin{array}{l}\text { Length at age } \\
1 \text { year }(\mathrm{cm})\end{array}$} & \multirow{2}{*}{$\begin{array}{l}\text { Reached high level of } \\
\text { education }(\%)\end{array}$} & \multicolumn{2}{|c|}{ Personal taxable income in 1990} & \multirow{2}{*}{$\begin{array}{l}\text { Became a } \\
\text { labourer }(\%\end{array}$} \\
\hline & & Finnish marks & Pounds & \\
\hline-72 & 9 (зоз) & 104.6 & $15370_{(276)}$ & $44_{(232)}$ \\
\hline-74 & $17(678)$ & 130.2 & $19140(623)$ & $32(534)$ \\
\hline-76 & $22(1044)$ & 136.8 & $20100(967)$ & $27(850)$ \\
\hline-78 & 20 (1103) & 138.1 & 20300 (1035) & $28(914)$ \\
\hline-80 & $17(703)$ & 138.5 & 20360 (650) & $26(598)$ \\
\hline$>80$ & 22 & 151.5 & 22270 & $20(352)$ \\
\hline All & $19(4252)$ & 135.2 & 19866 (3939) & $29(3480)$ \\
\hline$p$ value for trend & 0.001 & $<0.0001$ & & $<0.0001$ \\
\hline
\end{tabular}


(table 1). Even among boys born into middle class families, those who grew slowly in infancy tended to have low educational achievement and to become labourers. We conclude that biological processes linked to low growth rates during infancy lead to lifelong impairment of cognitive function, with consequent lower occupational status and lower income. Protection of infant growth will not only reduce infant mortality and childhood morbidity, but will improve cognitive function, and reduce morbidity from coronary heart disease and type 2 diabetes in adult life. ${ }^{25}$

\section{Authors' affiliations}

D J P Barker, DOHaD Division, University of Southampton, UK

J G Eriksson, T Forsén, National Public Health Institute, Helsinki, Finland

C Osmond, MRC Epidemiology Resource Centre, Southampton, UK

Competing interests: none declared
Correspondence to: Professor D J P Barker, DOHaD Division, Mailpoint 95, Southampton General Hospital, Southampton SO16 6YD, UK; dipb@mrc.soton.ac.uk

Accepted 24 September 2004

\section{REFERENCES}

1 Miller FJW, Court SDM, Knox EG, et al. The school years in Newcastle upon Tyne, 1952-1962. London: Oxford University Press, 1974.

2 Eriksson JG, Forsén T, Tuomilehto J, et al. Early growth and coronary heart disease in later life: longitudinal study. BMJ 2001;322:949-53.

3 Barker DJP, Forsén T, Uutela A, et al. Size at birth and resilience to effects of poor living conditions in adult life: longitudinal study. BMJ 2001;323:1273-6.

4 Freeman JV, Cole TJ, Chinn S, et al. Cross-sectional stature and weight reference curves for the UK, 1990. Arch Dis Child 1995;73:17-24.

5 Barker DJP, Eriksson JG, Forsén T, et al. Fetal origins of adult disease: strength of effects and biological basis. Int J Epidemiol 2002;31:1235-9.

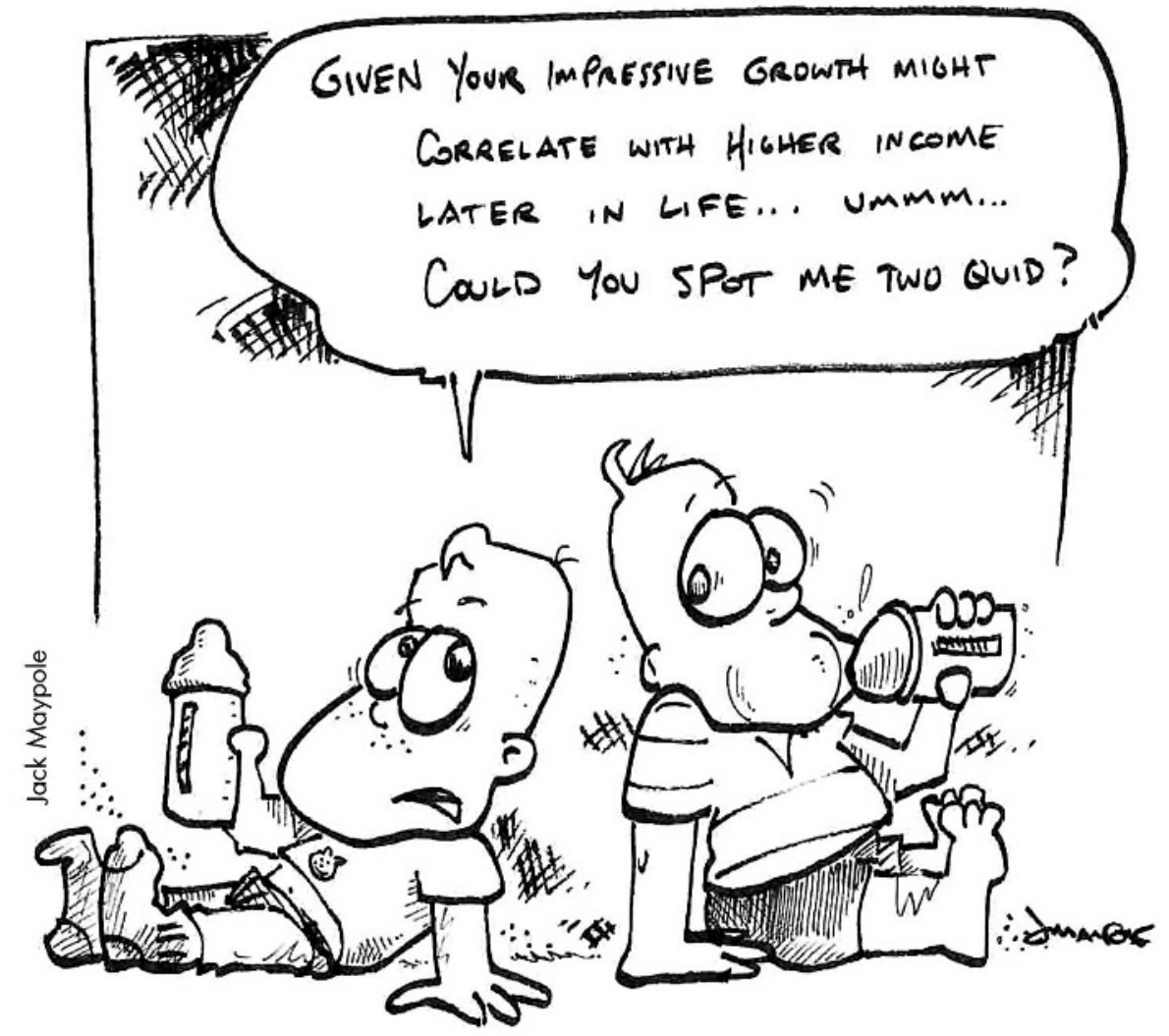

